\title{
ACCURACY ASSESSMENT OF FY-4A FIRE/HOTSPOT (FHS) PRODUCT IN WILDFIRE DETECTION
}

\author{
M.A.D.A. Celiz ${ }^{1 *}$, R. R. Landero ${ }^{1}$, J. A. Principe ${ }^{2}$, M.R.C.O. Ang ${ }^{2}$ \\ ${ }^{1}$ National Graduate School of Engineering, University of the Philippines Diliman, Quezon City - (maceliz1, rrlandero)@up.edu.ph \\ ${ }^{2}$ Dept. of Geodetic Engineering, University of the Philippines Diliman, Quezon City - (japrincipe, moang)@up.edu.ph
}

KEY WORDS: Fengyun 4A, VIIRS, wildfire detection, FHS

\begin{abstract}
:
The Fengyun-4A (FY-4A) is a relatively new geostationary satellite launched by the National Satellite Meteorological Center of China in 2016. With its Advanced Geosynchronous Radiation Imager (AGRI) instrument, FY-4A was able to provide a Fire and Hotspot product (FHS). This study explored the use of the FHS product in detecting wildfires and was compared to the similar fire detection product of the Visible Infrared Imaging Radiometer Suite (VIIRS) with the goal of assessing its effectiveness in the early detection and monitoring of wildfires. The FY-4A FHS and the VIIRS fire detection products have spatial resolutions of $2 \mathrm{~km}$ and $375 \mathrm{~m}$, and temporal resolutions of 15 minutes and 12 hours, respectively. The results of the comparative study showed that the FY-4A FHS product generated false negative results for detecting wildfires smaller than 20 pixels of VIIRS data $\left(\sim 2.82 \mathrm{~km}^{2}\right)$, at less than $4 \mathrm{MW}$ of radiative power, and brightness temperature lower than $330 \mathrm{~K}$. The FY-4A FHS product was also shown to be $50 \%$ accurate ( 1 correct and 1 false negative out of 2 samples) in detecting large wildfires $\left(>2.5 \mathrm{~km}^{2}\right)$ with high radiative power $(>4 \mathrm{MW})$ and high brightness temperature $(>330 \mathrm{~K})$. Lower accuracy may also be attributed to the presence of clouds that tend to obscure satellite images leading to an even lower accuracy of wildfire detection. For future studies, it is recommended that a comparison of the FY-4A FHS product be made with a more similar instrument, for example, the Advanced Himawari Imager 8/9 (AHI 8/9). It is also recommended to improve the fire and hotspot algorithm by incorporating a Normalized Brightness Temperature Difference Index (NBTDI) or by incorporating diurnal temperature cycle modelling for the older FY-2G data. Lastly, if available, a more reliable accuracy assessment can be done using FHS products of higher spatial resolution (at least $500 \mathrm{~m}$ ).
\end{abstract}

\section{INTRODUCTION}

\subsection{Background of the Study}

Wildfires are unplanned fires that burn in natural areas such as forests, grasslands, or prairies. These are often caused by human activities or natural phenomena such as lightning. These can happen at any time and anywhere (World Health Organization, 2021).

It is estimated that wildfire damage to forests can be as large as $6 \times 10^{6}$ hectares globally and detection and monitoring can be challenging (Mouillot et al., 2005). Climate change causing an increase in global temperature, drier conditions, increasing drought and changing wind and rain patterns add to the difficulty of predicting the location of wildfires especially during the dry months. According to the World Health Organization, there are 6.2 million people affected by wildfires and volcanic activity between 1998-2017. This includes around 2,400 deaths due to suffocation, injuries, and burns (World Health Organization, 2021). The key in preventing such large fires that can cause severe damages to infrastructures, livelihoods and even lives, is early detection of small fires, smokes, plumes and fire in water pixels.

\subsection{Literature Review}

The Fengyun-4A (FY-4A) was the second of China's new generation geostationary satellites which was launched on 10 December 2016 on a Long March 3B vehicle from the Xichang Satellite Launch Center in Sichuan Province, southwest of China. It has an altitude of 35,786 kilometers and is positioned at $104.5^{\circ}$ E. This is an improvement from China's first generation geostationary Fengyun-2G (FY-2G) satellite. Improvements in the FY-4A satellite include longer spacecraft design life, increase in observation efficiency from $5 \%$ to $85 \%$, and observation capabilities which now includes sound and lightning aside from images. The optical satellites also carry four instruments - the Advanced Geosynchronous Radiation Imager (AGRI) as a multiband imaging payload, the Geostationary Interferometric Infrared Sounder (GIIRS), the Lightning Mapping Imager (LMI), and the Space Environment Package (SEP). The FY-4A AGRI data includes a Fire and Hotspot (FHS) product.

The AGRI has 14 spectral bands, which is a leap from the data produced by FY-2G which covers only 5 bands. Previous fire detection algorithm studies of Z. Lin et al. (2019) used a midinfrared band of 3.4-4.0 $\mu \mathrm{m}$ from the FY-2G data. This band range is derived from both the incident radiation information of the sun and the emission information of the surface and clouds where radiation energy varies greatly (S. S. Chu et al., 2019). Therefore, the linear quantization method currently used by the imager cannot simultaneously consider the high- and lowtemperature targets (S. S. Chu et al., 2019). As an improvement of data collection of the FY-4A, the 3.5-4.0 $\mu \mathrm{m}$ range was assigned to two different bands. The dynamic range of channel 7 was set to capture high temperature areas, including hot spots and intense solar reflection. The dynamic range of channel 8 was set to normal and low-temperature areas and was mainly for monitoring cloud and fog (Lu et al., 2017) (Table 1).

The development of material data of the FY-4A was used in the study made by S. S. Chu et al. (2019) regarding automated volcanic hot-spot detection based on the AGRI infrared data. In this study, channel $7(3.75 \mu \mathrm{m})$ coupled with channel $13(12.0$ $\mu \mathrm{m})$ were utilized from the $4000 \mathrm{~m}$ spatial resolution raw data of 
the FY-4A images. Channels 7 and 13 are atmosphere windows, which are less affected by the atmosphere than the other channels (S. S. Chu et al., 2019).

\begin{tabular}{|c|c|c|c|l|}
\hline $\begin{array}{c}\text { Channel } \\
\text { number }\end{array}$ & $\begin{array}{c}\text { Centre } \\
\text { wavelength }\end{array}$ & $\begin{array}{c}\text { Chanel } \\
\text { width }\end{array}$ & $\begin{array}{c}\text { Spatial } \\
\text { resolution }\end{array}$ & \multicolumn{1}{|c|}{ Main application } \\
\hline 1 & 0.47 & 0.04 & 1.0 & Cloud, aerosol \\
\hline 2 & 0.65 & 0.2 & 0.5 & Fog, cloud \\
\hline 3 & 0.825 & 0.15 & 1.0 & Aerosol, vegetation \\
\hline 4 & 1.375 & 0.03 & 2.0 & Cirrus \\
\hline 5 & 1.61 & 0.06 & 2.0 & Cloud, Snow \\
\hline 6 & 2.25 & 0.25 & 2.0 & Cirrus, aerosols \\
\hline 7 & $3.75 \mathrm{H}$ & 0.50 & 2.0 & $\begin{array}{l}\text { Cloud, fire, moisture, } \\
\text { snow }\end{array}$ \\
\hline 8 & $3.75 \mathrm{~L}$ & 0.50 & 4.0 & $\begin{array}{l}\text { Land surface, fog, } \\
\text { cloud }\end{array}$ \\
\hline 9 & 6.25 & 0.90 & 4.0 & $\begin{array}{l}\text { Upper-level water } \\
\text { vapour }\end{array}$ \\
\hline 10 & 7.1 & 0.4 & 4.0 & $\begin{array}{l}\text { Mid-level water } \\
\text { vapour }\end{array}$ \\
\hline 11 & 8.5 & 1.0 & 4.0 & $\begin{array}{l}\text { Volcanic ash, cloud- } \\
\text { top phase }\end{array}$ \\
\hline 12 & 10.7 & 0.8 & 4.0 & $\begin{array}{l}\text { Land surface, cloud } \\
\text { top temperature }\end{array}$ \\
\hline 13 & 12.0 & 1.0 & 4.0 & $\begin{array}{l}\text { Sea-surface } \\
\text { temperature, land } \\
\text { surface temperature }\end{array}$ \\
\hline 14 & 13.5 & 0.6 & 4.0 & Cloud, air temperature \\
\hline
\end{tabular}

Table 1. Channel setting of FY-4A (from S. S. Chu et al., 2019)

A few authors have developed fire or hotspot algorithms for the Fengyun satellites. Lin, et al (2019), compared the fire algorithm developed for the FY-2G Stretched Visible and Infrared Spin Scan Radiometer (S-VISSR) with the fire detection from the Moderate Resolution Imaging Spectroradiometer (MODIS) on the NASA Earth Observing System satellites Terra and Aqua. The results of this study show that the algorithm for the FY-2G is stable and effective in detecting longer lasting and bigger fires and is able to detect early fires. However, it is ineffective in detecting small and sporadic fires.

Likewise, a volcanic hotspot detection algorithm called the FYVOLC, is developed for the FY-4A AGRI infrared data by $\mathrm{Chu}$, et al (2020). The FYVOLC incorporated a normalized brightness temperature difference index (NBDTI). The results of this study show a better performance compared to other volcanic algorithms with $89-94 \%$ correct detection, 6-11\% missed detection, and $4-11 \%$ false detection. Detection is affected by clouds.

Zhang, et al (2019) compared the performance of the FY-4A with the Himawari/AHI using a fire algorithm with a weighted mean on the radiation from the mid-infrared and thermal infrared channels. The result of this study shows that there is an agreement with the two instruments in terms of fire location, but has a difference on the total burned area.

\subsection{Significance of the Study}

Destructive wildfires could be prevented by early detection using remote sensing. Monitoring, especially during dry months, is essential in preventing these fires from spreading to large areas, including urbanized areas, and preventing further damage to the environment and infrastructure and even loss of lives.
The improvement in the data quality and collection of the FY-4A has provided opportunities in the early detection of wildfires. Some of these improvements include full disk imaging with AGRI, a temporal resolution of 15 minutes, spatial resolution of as high as 500 meters (500 - 4000 meters), and rapid scan of 2.5 minutes.

\section{STUDY AREAS}

\subsection{Benguet, Philippines}

Annual wildfires continue to ravage the mountainous region of Luzon, Philippines. In February 2020, several wildfires raged in Mt. Pulag, the highest peak in Luzon Island at 2,926 meters, straddling between the provinces of Benguet, Ifugao and Nueva Vizcaya. At least a thousand hectares of pine forest have been destroyed due to wildfires that lasted for weeks. Several areas were identified where these wildfires started. First is a nine-day forest fire which started in Barangay Kabayan Poblacion in Kabayan, Benguet. Another fire started in the jungles straddling the towns of Kabayan and Bokod and continued to spread out to Barangay Daclan in Kabayan. After this, a five-day forest fire hit the jungles in Barangay Eddet, located at the foot of Mt. Pulag. Inaccessibility or remoteness of the jungles caused difficulty for the local authorities in putting out and stopping the spread of these forest fires (Catindig, 2020).

On April 24, 2021, a ravaging forest fire was first reported in the town of Bokod in Benguet. This is located on the same mountain range as Mt. Pulag (Fig. 1). It has been reported that the fire first broke out a day before the news reached Sitio Pakak, Barangay Pito of the same town. It lasted until April 26 and had ravaged approximately three hectares of land. No casualties were reported (CNN Philippines, 2021).

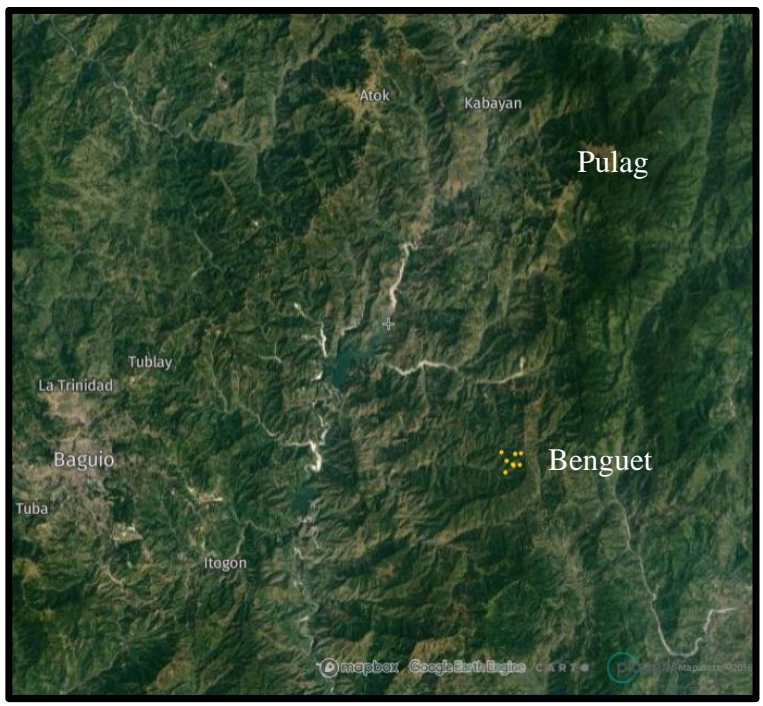

Figure 1. Detected fires (yellow pixels) on April 24-26, 202 from VIIRS in Benguet, Philippines

\subsection{Chitwan, Nepal and Valmiki, India}

Nepal and northern India are said to be experiencing the "worst of the decade" wildfires this year which resulted in Nepal's capital, Kathmandu, having the worst air quality in the world in April.

Wildfire season in the Himalayan states is from November to May, peaking in March to April. According to the authorities in Nepal, fires are deliberately induced by humans for clearing up 
grasslands and forests but it could also be attributed to the unusually dry season for the past two winters in the region which helped in the spread of fire. Nepal has recorded 2,700 wildfires since November 2020.

The Chitwan National Park in Nepal is a recognized World Heritage UNESCO site and is Nepal's first national park established in 1973. It is home to the single-horned Asiatic rhinoceros and the Bengal tiger. It is contiguous to the south to the Indian Tiger Reserve Valmiki National Park in India.

In April 12-16, 2021, several fires were detected with the VIIRS posted on the Global Forest Watch website (Fig. 2) and the VIIRS/MODIS on the NASA FIRMS website. Of the four days, more fires were reported on April 13 on both sites.

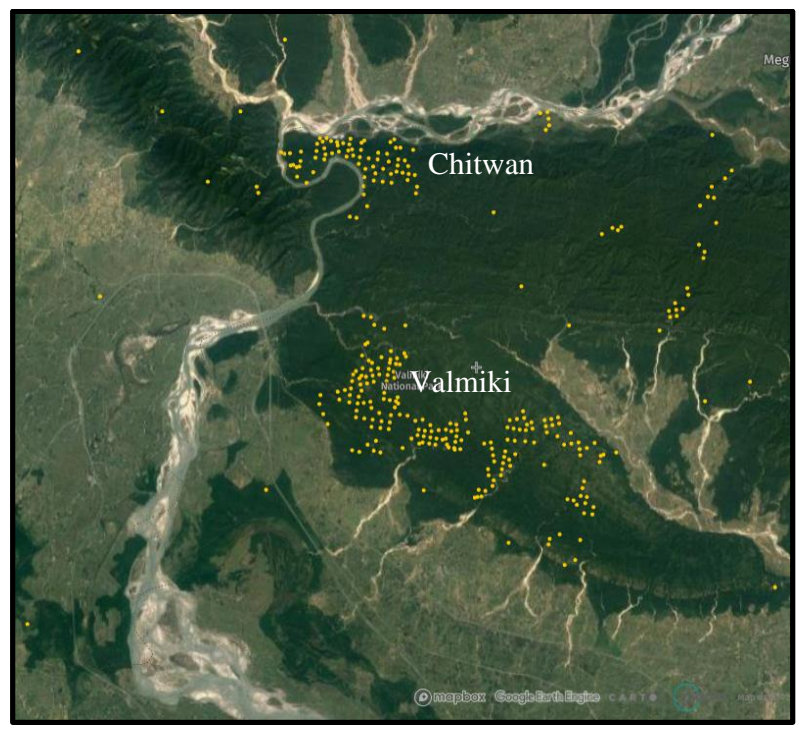

Figure 2. Detected fires (yellow pixels) on April 12-16, 2021 from VIIRS in the west Chitwan National Park, Nepal and Valmiki National Park, India.

\section{METHODOLOGY}

This study focused on comparing and analyzing readily available fire and hotspot data from the National Satellite Meteorological Center of China and the fire detection product from the Visible Infrared Imaging Radiometer Suite (VIIRS) before, during and after the peak of reported wildfires in the study areas. Flowchart of the methodology is shown in Fig. 3.

\subsection{Data}

Data collection involves selection of fire and hotspot L2 images of FY-4A from the National Satellite Meteorological Center of China website or by using the FY Satellite Download Toolkit. These images are in the form on *.nc files, with at least a 15 minute temporal resolution, for the period of April 11-17 for the west Chitwan-Valmiki region in Nepal and India, and April 2226 for the Benguet area. A total of 193 and 271 images were downloaded, respectively.

The VIIRS data were gathered from the Global Forest Watch website, for the same periods for the two study areas. The data, including total alerts, radiative power, and brightness, has a temporal resolution of 12 hours. The detection time interval for both areas is 12 hours. Fire detection in Benguet is between 5:30-
6:00 AM and PM while for the west Chitwan-Valmiki region, it is between 7:00-8:00 AM and PM. (Table 2)

\begin{tabular}{|l|c|c|}
\hline Description & FY-4A & VIIRS \\
\hline $\begin{array}{l}\text { Spatial } \\
\text { Resolution }\end{array}$ & $2 \mathrm{~km}$. & $375 \mathrm{~m}$. \\
\hline $\begin{array}{l}\text { Temporal } \\
\text { resolution }\end{array}$ & $15 \mathrm{mins}$ & $12 \mathrm{hrs}$ \\
\hline Data values & detected fire & $\begin{array}{c}\text { detected fire, radiative } \\
\text { power (MW), } \\
\text { brightness temp. (K) }\end{array}$ \\
\hline Source & satellite.ncmc.org.cn & globalforestwatch.org \\
\hline
\end{tabular}

Table 2. Summary of VIIRS and FY-4A data desciptions.

\subsection{Methods}

All the FY-4A.nc images were translated to *.tif files using the OSGeo4W Shell.

The *.tif files were then clipped using the SNAP software by inputting the coordinates of the boundaries of the study areas (Table 3).

\begin{tabular}{|l|c|c|}
\hline \multicolumn{1}{|c|}{ Study Area } & $\begin{array}{c}\text { Coordinate } \\
\text { Boundaries: } \\
\text { Corner 1 }\end{array}$ & $\begin{array}{c}\text { Coordinate } \\
\text { Boundaries: } \\
\text { Corner 2 }\end{array}$ \\
\hline $\begin{array}{l}\text { Benguet, } \\
\text { Philippines }\end{array}$ & $120^{\circ} \mathrm{E}-25^{\circ} \mathrm{N}$ & $128^{\circ} \mathrm{E}-15^{\circ} \mathrm{N}$ \\
\hline $\begin{array}{l}\text { Chitwan-Valmiki, } \\
\text { Nepal and India }\end{array}$ & $75^{\circ} \mathrm{E}-35^{\circ} \mathrm{N}$ & $90^{\circ} \mathrm{E}-25^{\circ} \mathrm{N}$ \\
\hline
\end{tabular}

Table 3. Geographical boundaries of study areas.

The Benguet and the west Chitwan-Valmiki data were georeferenced using 6 and 3 ground control points (GCPs), respectively. The tabulated VIIRS data were then loaded in the QGIS software as a delimited text layer and compared with the georeferenced FY-4A raster files.

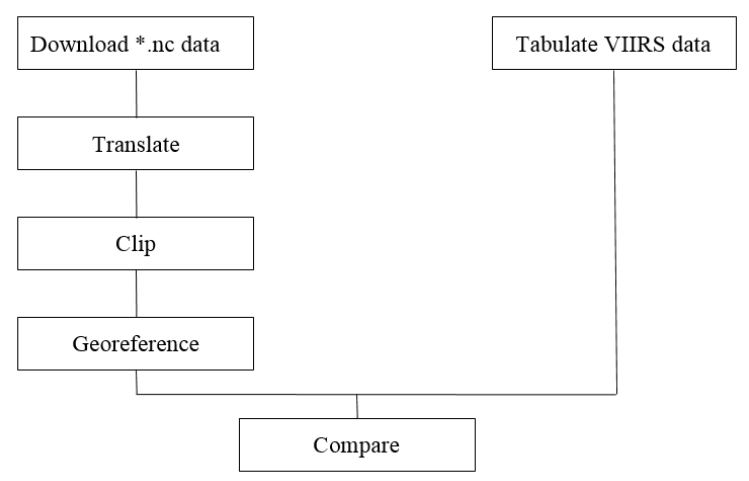

Figure 3. Flowchart of the techniques and methods used in processing of FY-4A and VIIRS data.

\section{RESULTS AND DISCUSSION}

\subsection{Benguet, Philippines}

Results show that the fire occurrence in Benguet was detected by the VIIRS. Between April 24 to 25, a minimum of 1 pixel and a maximum of 3 pixels were detected with approximate areas ranging from 0.1 to $0.4 \mathrm{sq}$. $\mathrm{km}$. These were not captured in the FY-4A images. 


\subsection{Chitwan, Nepal and Valmiki, India}

Numerous fire occurrences were detected in west Chitwan, Nepal on the VIIRS between April 12 to April 16, 2021. On April 12, 1 fire pixel was detected and continued to expand until the night of April 13 where 22 fire pixels were detected. Fire pixels were detected until April 16, 2021.

Meanwhile, using FY-4A data, fires were detected on April 13 at 900 and 1000 UTC, with 3 pixels and approximately 6 sq. km. each. No fire occurrence was detected at the same time as in VIIRS data since the satellite did not pass over the area at that time.

In Valmiki, India, the same trend of fire severity was detected. Eighteen fire pixels were detected on April 12, 2021 and increased to 24 fire pixels on April 13. It declined to 4 to 6 pixels between April 14 to 16 . The FY-4A data, on the other hand, detected only 2 fire pixels in the morning of April 13, coinciding with the day with most fire pixels detected by the VIIRS data.

\subsection{Radiative power and brightness temperature}

The radiative power and brightness temperature data were extracted from the VIIRS data. The Benguet fires are characterized by low to high radiative power (Fig. 4) and low to high brightness temperature values (Fig. 5). In particular, the fire on the morning of April 25 has high radiative power and high brightness temperature. The approximate area of the fire, based on the number of pixels, is $0.423 \mathrm{sq}$. $\mathrm{km}$ (Table 4). No fire pixel is detected by the FY-4A data in this area.

Wildfires in the west Chitwan area are characterized by low to moderate radiative power (Fig. 6) and low to moderate brightness temperature values (Fig. 7). The approximate areas of the wildfire occurrences are 0.564 to 4.230 sq. $\mathrm{km}$ (Table 4). No fire pixel is detected by the FY-4A data in this area.

The wildfires at the Valmiki area are characterized by low to high radiative power (Fig. 8) and low to high brightness temperature values (Fig. 9). In particular, the fires in the mornings of April 12 and 13 have high radiative power and high brightness temperature values (Fig. 6). The approximate wildfire areas from these two instances are 2.538 and 2.830 sq. km., respectively. Only the fire on the morning of April 13 had a fire detection from the FY-4A data. All other fires at the Valmiki area had approximate areas of 0.564 to $4.230 \mathrm{sq}$. km (Table 4). These are not detected by the FY-4A data.

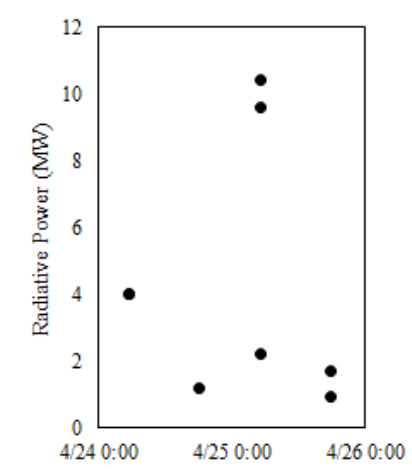

Figure 4. Radiative power (MW) of fire pixels detected in Benguet, Philippines by VIIRS.

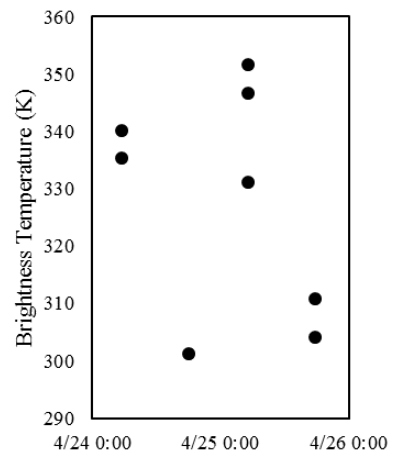

Figure 5. Fire pixels in terms of brightness temperature $(\mathrm{K})$ in Benguet, Philippines by VIIRS.

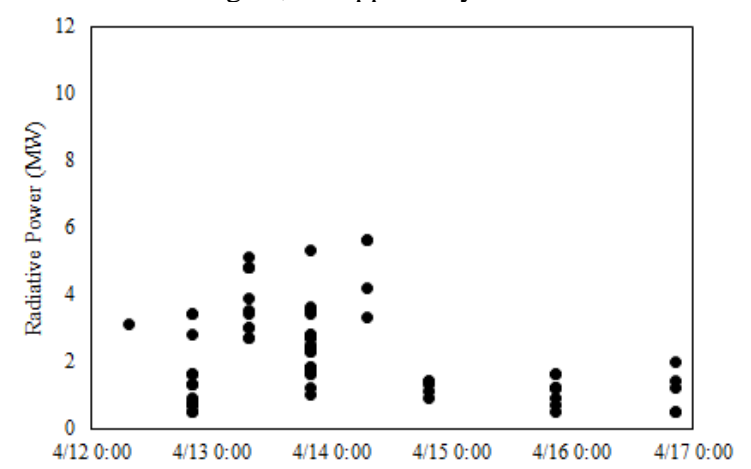

Figure 6. Radiative power (MW) of fire pixels detected in west Chitwan, Nepal by VIIRS.

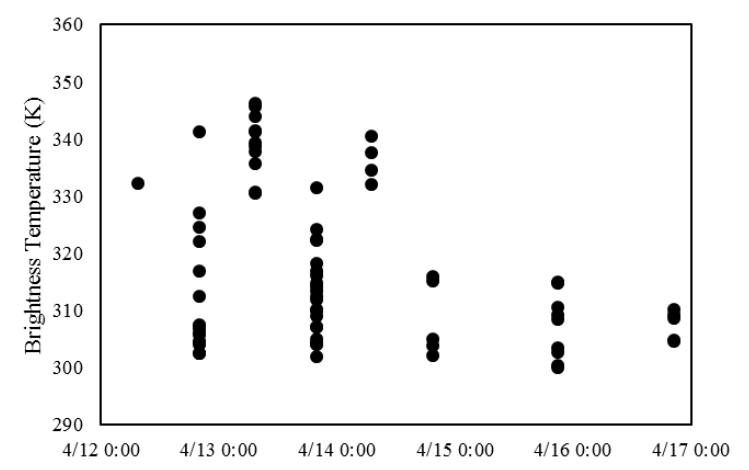

Figure 7. Fire pixels in terms of brightness temperature $(K)$ in west Chitwan, Nepal by VIIRS.

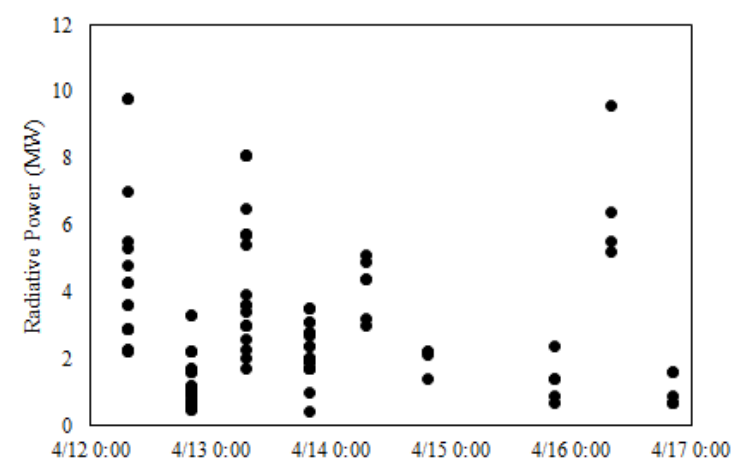

Figure 8. Radiative power (MW) of fire pixels detected in Valmiki, India by VIIRS. 


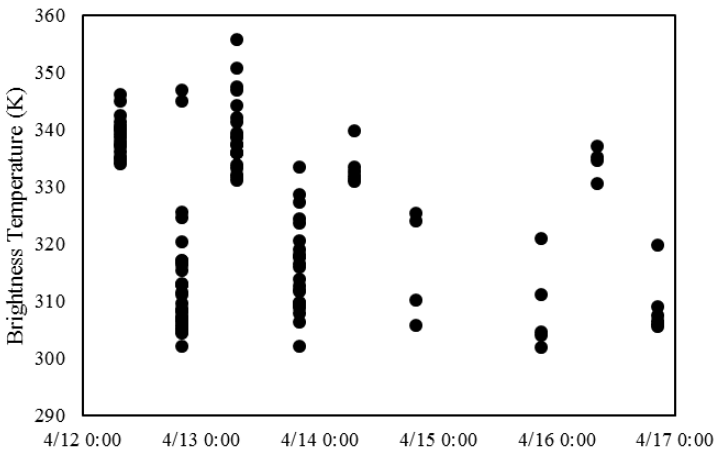

Figure 9. Fire pixels in terms of brightness temperature $(\mathrm{K})$ in Valmiki, India by VIIRS.

\begin{tabular}{|l|c|c|c|}
\hline Study Area / Date / Time & $\begin{array}{c}\text { Radiative } \\
\text { Power } \\
\text { (MW) }\end{array}$ & $\begin{array}{c}\text { Brightness } \\
\text { Temp. (K) }\end{array}$ & $\begin{array}{c}\text { Area } \\
\text { (sq. km.) }\end{array}$ \\
\hline Benguet / April 25 / AM & 7.400 & 343.133 & 0.423 \\
\hline Chitwan / April 13 / AM & 3.791 & 339.236 & 1.551 \\
\hline Chitwan / April 14 / AM & 4.675 & 336.200 & 0.564 \\
\hline Valmiki / April 12 / AM & 4.367 & 338.916 & 2.538 \\
\hline Valmiki / April 12 / PM & 1.327 & 313.400 & 4.230 \\
\hline Valmiki / April 13 / AM & 4.555 & 339.485 & 2.820 \\
\hline Valmiki / April 13 / PM & 2.225 & 315.708 & 3.384 \\
\hline
\end{tabular}

Table 4. Comparison between radiative power, brightness temperature, and area.

\section{CONCLUSIONS AND RECOMMENDATIONS}

In general, the performance of the FY-4A Fire and Hotspot product (FHS) was not effective in detecting and monitoring wildfires. The results of the comparative study showed that the FY-4A FHS product generated false negative results for detecting wildfires smaller than 20 pixels of VIIRS data $\left(\sim 2.82 \mathrm{~km}^{2}\right)$, at less than $4 \mathrm{MW}$ of radiative power and brightness temperature lower than $330 \mathrm{~K}$.

The FY-4A FHS product was also shown to be $50 \%$ accurate (1 correct and 1 false negative out of 2 samples) in detecting large wildfires $\left(>2.50 \mathrm{~km}^{2}\right)$ with high radiative power $(>4 \mathrm{MW})$ and high brightness temperature (>330 K). Lower accuracy may also be attributed to the presence of clouds that tend to obscure satellite images leading to an even lower accuracy of wildfire detection.

For future studies, it is recommended that a comparison of the FY-4A FHS product be made with a more similar instrument, for example, the Advanced Himawari Imager 8/9 (AHI 8/9). It is also recommended to improve the fire and hotspot algorithm by incorporating a Normalized Brightness Temperature Difference Index (NBTDI) or by incorporating diurnal temperature cycle modelling for the older FY-2G data. Lastly, if available, a more reliable accuracy assessment can be done using FHS products of higher spatial resolution (at least $500 \mathrm{~m}$ ).

\section{ACKNOWLEDGEMENT}

Authors would like to thank the National Satellite Meteorological Center of China, Global Forest Watch, and NASA's Earth Science Data Systems Program for the data used in this study.

\section{REFERENCES}

Catindig, R., 2020. "Wildfire destroys 1,000 hectares of Benguet forest". Philippine Star. https://www.philstar.com/nation/2020 /02/25/1995773/.

Chu, S. S., Zhu, L., Sun, H. F., Li, Q. W., Zhang, X. R., Chen, T. T., Qiao, L., Zhu, W. R., Zhao, D. X., and Zhang, Y. H. 2020. Automated volcanic hot-spot detection based on FY-4A/AGRI infrared data, International Journal of Remote Sensing, 41:6, 2410-2438, DOI: 10.1080/01431161.2019.1688887

CNN Philippines, 2021. "Forest fire hits Benguet town". https://www.cnnphilippines.com/regional/2021/4/24/Bokodforest-fire.html

ESA Earth Observation Portal.

2002. https://directory.eoportal.org/web/eoportal/satellitemissions/content/-/article/fy-4

Fire Information for Resource Management System. 2021 https://firms.modaps.eosdis.nasa.gov (28 May 2021)

Ganci, G., A. Vicari, A. Cappello, and C. Del Negro. 2012. An Emergent Strategy for Volcano Hazard Assessment: From Thermal Satellite Monitoring to Lava Flow Modeling. Remote Sensing of Environment 119: 197-207. doi:10.1016/j.rse.2011.12.021.

Ganci, G., A. Vicari, L. Fortuna, and C. Del Negro. 2011. The HTSAT Volcano Monitoring System Based on Combined Use of SEVIRI and MODIS Multispectral Data." Annals of Geophysics 54 (5): 3025-3029. doi:10.4401/ag-5338.

Global Forest Watch .2021. https://www.globalforestwatch.org (28 May 2021)

Lin, Z., Chen, F., Li, B., Yu, B., Jia, H., Zhang, M., and Liang, D. 2019. A Contextual and Multitemporal Active-Fire Detection Algorithm Based on FengYun-2G S-VISSR Data. IEEE Transactions on Geoscience and Remote Sensing, vol. 57, no. 11, pp. 8840-8852, Nov. 2019, doi: 10.1109/TGRS.2019.2923248.

Lu, F., Zhang, X. H., Chen, B. Y., Liu, H., Wu, R. H., Han, Q., Feng, X. H., Li, Y., and Zhang, Z. Q. 2017. "FY-4 Geostationary Meteorological Satellite Imaging Characteristics and Its Application Prospects.” Journal of Marine Meteorology 37 (2): 1-12. doi:10.19513/j.cnki.issn2096-3599.2017.02.001.

Mouillot, F., and Field, C. B., "Fire history and the global carbon budget: A 1 degrees $\times 1$ degrees fire history reconstruction for the 20th century," Global Change Biol., vol. 11, no. 3, pp. 398420,2005

Sharma, G., 2021. "Nepal battles worst forest fires in years as air quality drops" in Thomas Reuters Foundation news. https://news.trust.org/item/20210409065844-yishm/.

The Third Pole, 2021. "Fires ravage forests in Himalayas, threatening health and biodiversity". https://www.thethirdpole.net/en/climate/fires-ravage-forestshimalayas-threatening-health-biodiversity/

UNESCO - World Heritage Convention. 2021. https://whc.unesco.org/en/list/284

WHO - World Health Organization. 2021.

https://www.who.int/health-topics/wildfire

Zhang, Z. Q., Lu, F., Fang, X., Tang, S. H., Zhang, X. H., Xu, Y. L., Han, W. 2017. Application and Development of FY-4 Meteorological Satellite. Aerospace Shanghai 34 (04): 8-19. doi:10.19328/j.cnki.1006-1630.2017.04.002 


\section{APPENDIX}

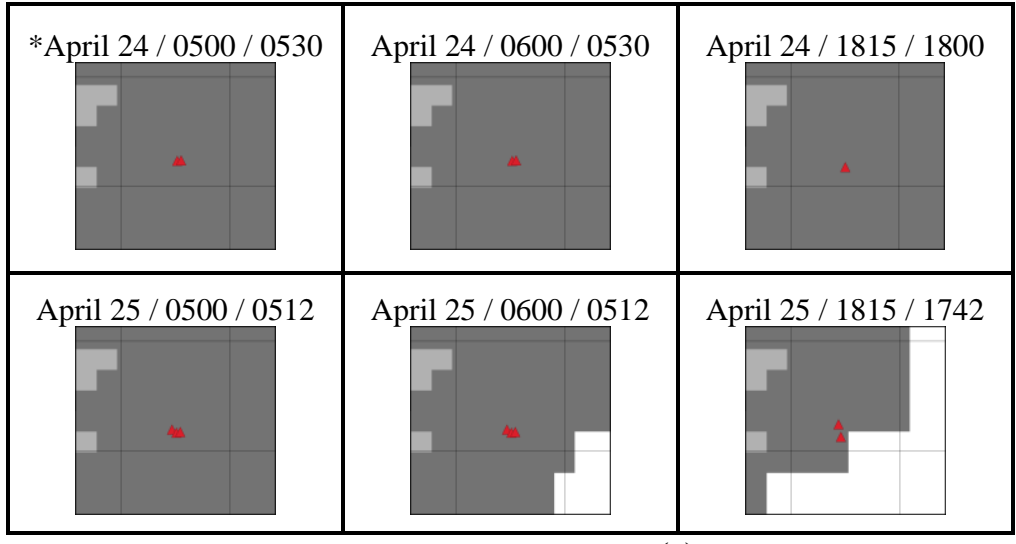

(a)

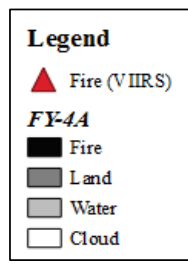

*Date (Month Day)/ Time in UTC (FY-4A product) / Time in UTC (VIIRS product)

All images are acquired in 2021.

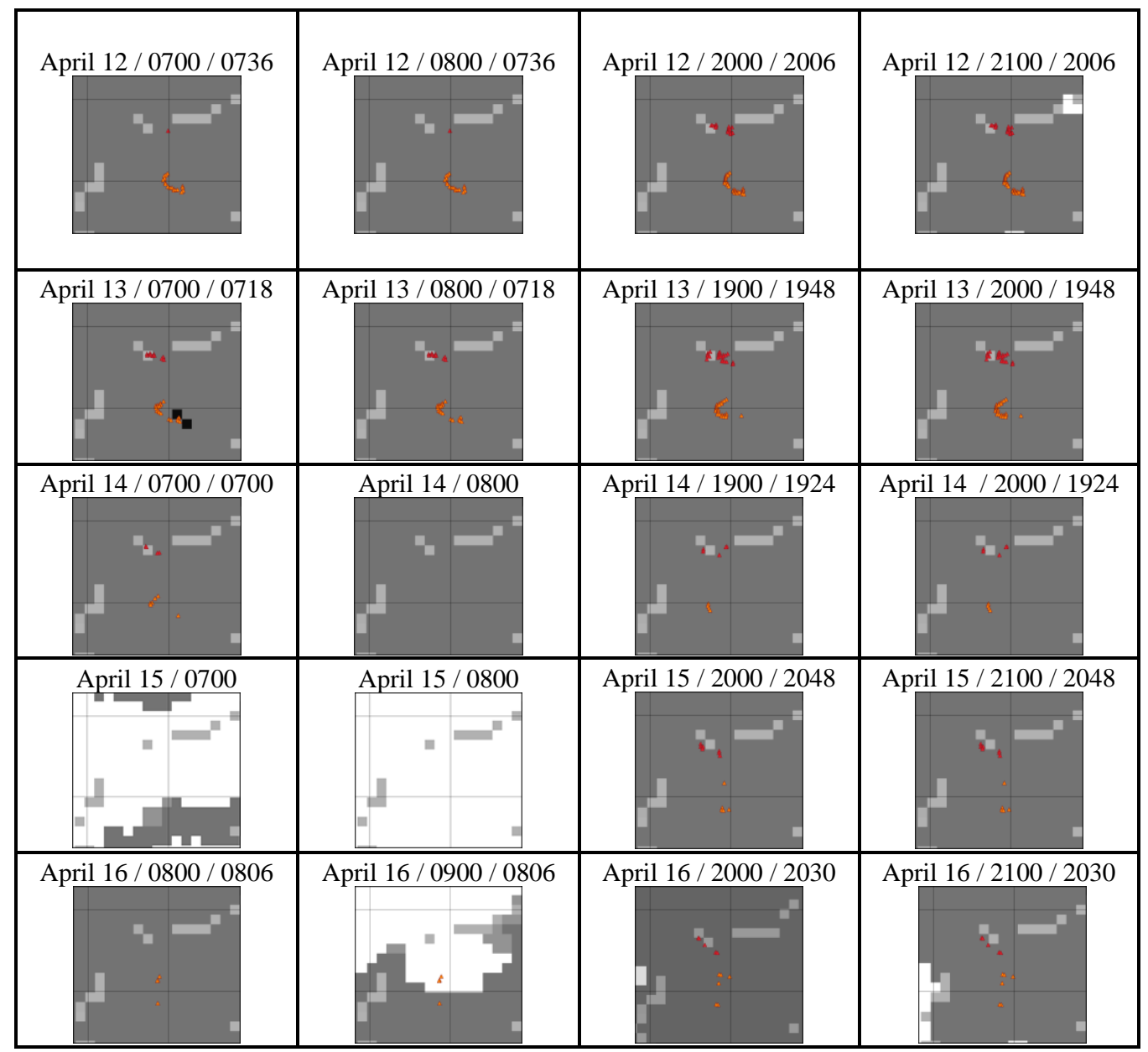

\begin{tabular}{|l|}
\hline Legend \\
$\Delta$ Chitwan Fire (VIIRS) \\
$\triangle$ Valmiki Fire (VIIRS) \\
$F Y$-4A \\
Fire \\
Land \\
Water \\
$\square$ Cloud \\
\hline
\end{tabular}

*Date (Month Day)/ Time in UTC (FY-4A product) / Time in UTC (VIIRS product)

All images are acquired in 2021.

(b)

Figure 9. FY-4A and VIIRS fire detection products in (a) Benguet, Philippines; (b) West Chitwan, Nepal and Valmiki, India. 